\title{
Isolation and characterization of microsatellite loci in the rock scallop (Spondylus calcifer) (Bivalvia: Spondylidae) from the Northern Gulf California, Mexico
}

\author{
A. Munguia-Vega $\cdot$ G. Soria $\cdot$ T. Pfister $\cdot$ \\ R. Cudney-Bueno
}

Received: 4 November 2009/Accepted: 6 November 2009/Published online: 26 November 2009

(C) The Author(s) 2009. This article is published with open access at Springerlink.com

\begin{abstract}
Twelve microsatellite loci were isolated from an enriched genomic library of the rock scallop (Spondylus calcifer). One locus was monomorphic. Overall polymorphic loci, the mean numbers of alleles per locus at one locality was 9.6 (range 3-16), and the average observed and expected heterozygosities were 0.650 and 0.707 , respectively. Three loci deviated from Hardy-Weinberg equilibrium, and from these, one locus had and excess of heterozygotes and the other two loci showed deficits of heterozygotes likely due to the presence of null alleles. No evidence of linkage disequilibrium was found among loci. These loci are the first microsatellites ever reported for the monotypic family Spondylidae, and will be useful to validate the predictions of oceanographic larval transport models and connectivity between patchy reefs within fishing areas and marine reserves in the northern Gulf of California, Mexico.
\end{abstract}

Keywords Gulf of California · Fisheries ·

Spondylus calcifer - Rock scallop · Connectivity ·

Microsatellites

\footnotetext{
A. Munguia-Vega $(\square)$

Conservation Genetics Laboratory, School of Natural Resources and the Environment, BioSciences East 317, The University of Arizona, Tucson, AZ 85721, USA

e-mail: airdrian@email.arizona.edu

G. Soria - T. Pfister · R. Cudney-Bueno

School of Natural Resources and the Environment, BioSciences East 325D, The University of Arizona,

1311 E 4th st., Tucson, AZ 85721, USA

R. Cudney-Bueno

Institute of Marine Sciences, Long Marine Laboratories, University of California Santa Cruz, 100 Schaffer Road,

Santa Cruz, CA 95060, USA
}

The rock scallop, Spondylus calcifer, is geographically distributed from de coast of Peru to the northern Gulf of California (NGC), Mexico (Poutiers 1995). In the Gulf of California, the species constitutes a fishing resource for small-scale fisheries throughout the coast of Sonora, Baja California, the midriff island region, and Baja California Sur (Villalejo-Fuerte and Muñetón-Gómez 2002; CudneyBueno and Turk-Boyer 1998; Cudney-Bueno and Rowell 2008). S. calcifer inhabits mainly rocky reef areas from the inter-tidal to $55 \mathrm{~m}$ in depth (Poutiers 1995). It is a gonochoric species and reaches sexual maturity between 2.5 and 4 years of age. The species can live to at least 10 12 years (Cudney-Bueno and Rowell 2008) and attain $25 \mathrm{~cm}$ in shell height. The fertilization is external and planktonic stages are followed by settlement of sessile individuals. In the Gulf of California, S. calcifer has a short spawning period from July to October (Villalejo-Fuerte et al. 2002; Cudney-Bueno and Rowell 2008).

A counterclockwise connectivity via dispersion of larvae among stocks has been hypothesized based on oceanographic circulation for the NGC (Marinone et al. 2008; Cudney-Bueno et al. 2009). In order to validate these hypotheses and provide management and conservation guidelines for this species, information related to population genetic structure is needed. Examining the level of biological connectivity among populations of harvested species is critical to design and establish networks of marine protected areas in the region.

An enriched genomic DNA library was constructed following a modified version of Glenn and Schable (2005). For that purpose, DNA was extracted using the DNeasy Blood and Tissue Kit (Qiagen) from five individuals collected from Angel de la Guarda island in the NGC. Genomic DNA was digested with Rsal (NEB), and fragments ligated to double-stranded SuperSNX-24 linkers. 


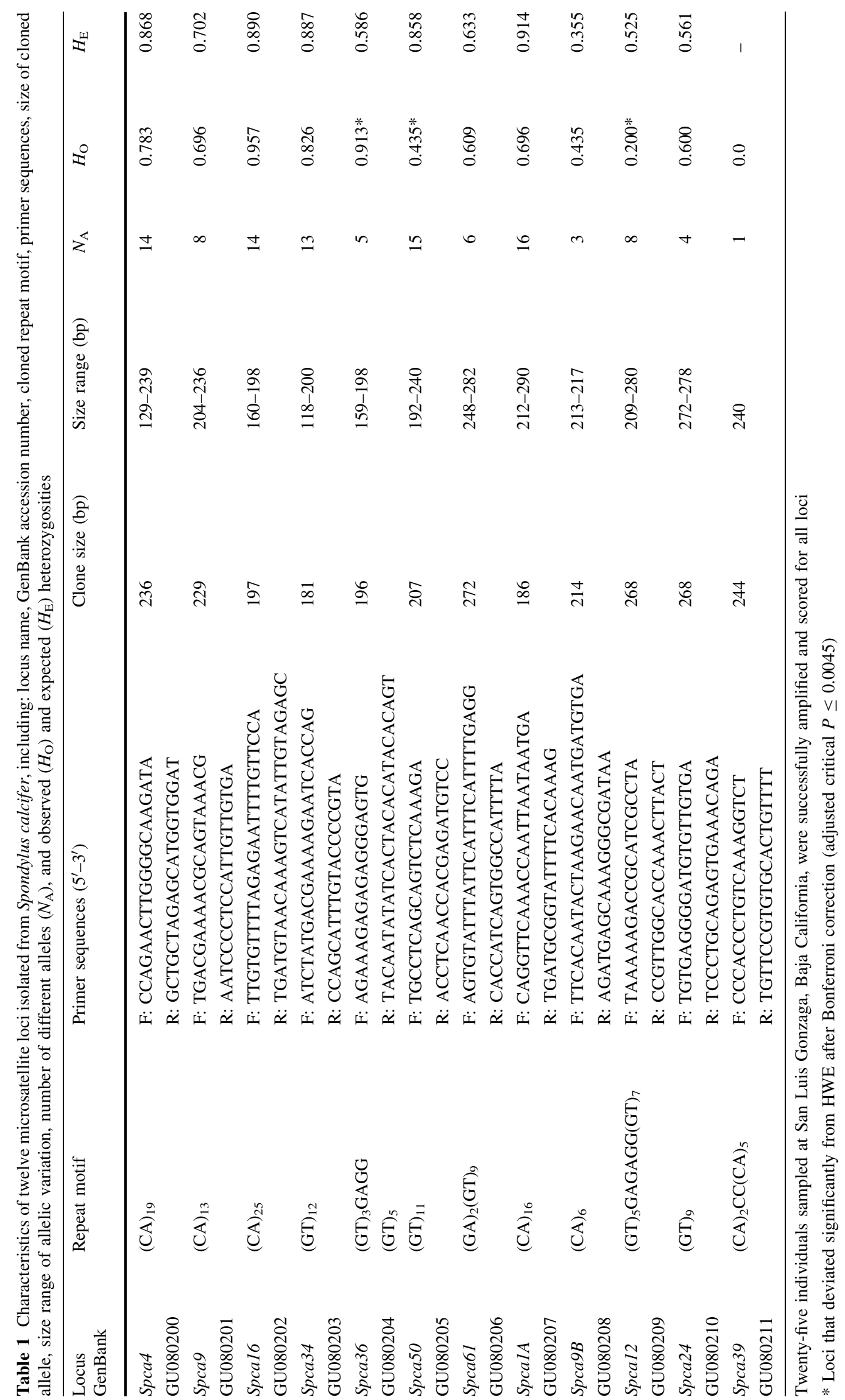


Linker-ligated fragments that ranged from 300 to $1,200 \mathrm{bp}$ were recovered by means of the polymerase chain reaction (PCR), SuperSNX-24 forward primer, and Platinum highfidelity Taq DNA polymerase (Invitrogen). Later, "linkerligated" fragments were hybridized to $5^{\prime}$-biotinylated microsatellite oligonucleotide probes $(\mathrm{GT})_{15}$ and $(\mathrm{CT})_{15}$. Hybridized fragments were captured on streptavidin-coated paramagnetic beads (Dynal), recovered by PCR, ligated into the vector PCR4-TOPO (Invitrogen), and transformed into TOP10 chemically competent $E$. coli cells (Invitrogen) following the manufacturer's protocol. Clones were amplified by PCR using M13 primers, visualized on $2 \%$ agarose gels and selected for sequencing based on checking for successful amplification and differing amplicon sizes. One-hundred and ninety-six clones were directly sequenced in both directions on an Applied Biosystems 3730XL DNA Analyzer using the BigDye Terminator Cycle Sequencing Kit. One-hundred and twenty $(62.5 \%)$ of the clones had recognizable microsatellite sequences but from those only 42 had adequate flanking regions to design primers using PRIMER3 (Rozen and Skaletsky 2000). The universal M13 primer was added at the $5^{\prime}$ end of the forward primers to allow fluorescent labeling of the amplicons using M13 labeled oligonucleotides (Schuelke 2000). Reverse primers were designed with a "pig-tail" at the $5^{\prime}$ end to reduce variability in adenylation of amplification products (Brownstein et al. 1996).

PCRs were performed in $15 \mu \mathrm{l}$ volumes containing $\sim 40 \mathrm{ng}$ genomic DNA, $1 \times$ PCR buffer, $0.2 \mathrm{mM}$ each dNTP, $0.02 \mu \mathrm{M}$ of the unlabeled M13-tailed forward primer, $0.2 \mu \mathrm{M}$ of the reverse and $0.2 \mu \mathrm{M}$ of the fluorescentlylabeled M13 primers, $1.5 \mathrm{mM} \mathrm{MgCl} 2$, and $0.5 \mathrm{U}$ taq DNA polymerase (Invitrogen), and $0.2 \%$ BSA. All loci were amplified with a touchdown protocol that included an initial denaturation at $94^{\circ} \mathrm{C}$ for $5 \mathrm{~min}, 15$ cycles at $94^{\circ} \mathrm{C}$ for $30 \mathrm{~s}$, annealing at $65-50^{\circ} \mathrm{C}$ for $30 \mathrm{~s}\left(1^{\circ} \mathrm{C}\right.$ decrease in each cycle), $72^{\circ} \mathrm{C}$ for $30 \mathrm{~s}$, followed by 40 cycles at $94^{\circ} \mathrm{C}$ for $30 \mathrm{~s}, 55^{\circ} \mathrm{C}$ for $30 \mathrm{~s}, 72^{\circ} \mathrm{C}$ for $30 \mathrm{sec}$ and a final extension of $72^{\circ} \mathrm{C}$ for 5 min. Loci were genotyped on an ABI PRISM 3730 Genetic Analyzer (Applied Biosystems), alleles were scored using GENOTYPER 3.7 (Applied Biosystems) and their sizes classified into bins with FLEXIBIN (Amos et al. 2007). We used GENALEX 6.2 (Peakall and Smouse 2006) to calculate observed and expected heterozygosities and probabilities of identity, GENEPOP 3.4 (Raymond and Rousset 1995) to estimate deviations from Hardy-Weinberg equilibrium (HWE) and to test for linkage disequilibrium (LD) between pairs of loci, and MICRO-CHECKER 2.2.3 (Van Oosterhout et al. 2004) to estimate the frequency of null alleles and other genotyping errors. Adjusted $P$ values were obtained using a sequential Bonferroni test for multiple comparisons (Rice 1989). The experiment-wise error rate was predefined at 0.05 .
Twelve di-nucleotide loci were successfully amplified and scored on 25 individuals sampled from San Luis Gonzaga, Baja California (Table 1). One locus (Spca39) was monomorphic, but the size of the observed allele differed from the cloned allele, suggesting polymorphism is present elsewhere. Overall polymorphic loci, the mean number of alleles per locus was 9.6 (range 3-16). Average observed and expected heterozygosities were 0.650 and 0.707, respectively. Three loci (Spca36, Spca50, Spca12) deviated from HWE. Locus Spca36 had an excess of heterozygotes, while loci Spca50 and Spca12 showed deficits of heterozygotes and evidence of null alleles according to the distribution of homozygote-size classes. The estimated frequencies of the null alleles were 0.245 and 0.270 , respectively (Van Oosterhout et al. 2004). Although null alleles at microsatellite loci seem to be commonly reported for some invertebrates, including bivalves (Geist et al. 2003; Kaukinen et al. 2004), they could also be confounded with Wahlund effects, population bottlenecks and inbreeding. MICROCHECKER did not detect any other genotyping error among the loci (e.g. stuttering, largeallele dropout). No evidence of significant LD was found among the tests for each pair of loci (all adjusted $P$ values $>0.0009$ ). The probability of identity calculated was $1.4 \times 10^{-12}$. These markers are the first microsatellite loci reported for the monotypic family Spondylidae.

Acknowledgments We acknowledge the financial support provided from The David and Lucile Packard Foundation, The Wallace Research Foundation, The Nature Conservancy and the Conservancy's RJ KOSE Grant Program. AMV received a CONACYT graduate scholarship (\#158622). We wish to thank commercial divers of the Northern Gulf of California for their support with the collection of samples. Research was conducted under permit \#SGPA/DGVS/ 13159 of the Dirección General de Vida Silvestre; Secretaría de Medio Ambiente y Recursos Naturales (SEMARNAT) of Mexico. This is a scientific contribution of the PANGAS project: www.pangas.arizona.edu.

Open Access This article is distributed under the terms of the Creative Commons Attribution Noncommercial License which permits any noncommercial use, distribution, and reproduction in any medium, provided the original author(s) and source are credited.

\section{References}

Amos W, Hoffman JI, Frodsham A, Zhang L, Best S, Hill AVS (2007) Automated binning of microsatellite alleles: problems and solutions. Mol Ecol Notes 7:10-14

Brownstein MJ, Carpten D, Smith JR (1996) Modulation of nontemplated nucleotide addition by Taq DNA polymerase: primer modifications that facilitate genotyping. Biotech 20:1004-1010

Cudney-Bueno R, Rowell K (2008) Establishing a baseline for management of the rock scallop Spondylus calcifer (Carpenter 1857): growth and reproduction in the upper Gulf of California, Mexico. J Shellfish Res 27:625-632 
Cudney-Bueno R, Turk-Boyer PJ (1998) Pescando entre mareas del alto Golfo de California. Centro Intercultural de Estudios de Desiertos y Océanos. Puerto Peñasco, Sonora, Mexico

Cudney-Bueno R, Lavín MF, Marinone SG, Raimondi PT, Shaw W (2009) Rapid effects of marine reserves via larval dispersal. PLOS ONE 4:e4140

Geist J, Rottmann O, Schroder W, Kuhn R (2003) Development of microsatellite markers for the endangered freshwater pearl mussel Margaritifera margaritifera L (Bivalvia: Unionoidea). Mol Ecol Notes 3:444-446

Glenn TC, Schable NA (2005) Isolating microsatellite DNA loci. Methods Enzymol 395:202-222

Kaukinen KH, Supernault KJ, Miller KM (2004) Enrichment of tetranucleotide microsatellite loci from invertebrate species. J Shellfish Res 23:621-626

Marinone SG, Ulloa MJ, Parés-Sierra A, Lavín MF, Cudney-Bueno R (2008) Connectivity in the northern Gulf of California from particle tracking in a three-dimensional numerical model. J Mar Syst 71:149-158

Peakall R, Smouse PE (2006) GENALEX 6: genetic analysis in excel population genetic software for teaching and research. Mol Ecol Notes 6:288-295

Poutiers JM (1995) Bivalvos. In: Fischer W, Krupp F, Schneider W, Sommer C, Carpenter KE, Niem VH (eds) Guía FAO para la identificación de especies para los fines de la pesca: Pacífico centro oriental Volumen I. FAO, Roma, pp 99-222

Raymond M, Rousset F (1995) GENEPOP (version 1.2): population genetics software for exact tests and ecumenicism. J Hered $86: 248-249$

Rice WR (1989) Analyzing tables of statistical tests. Evol 43:223-225

Rozen S, Skaletsky H (2000) Primer 3 on the WWW for general users and for biologist programmers. In: Krawetz S, Misener S (eds) Bioinformatics methods and protocols: methods in molecular biology. Humana Press, Totowa, New Jersey, pp 365-386

Schuelke M (2000) An economic method for the fluorescent labeling of PCR fragments. Nat Biotechnol 18:233-234

Van Oosterhout C, Hutchinson WF, Wills DPM, Shipley P (2004) Micro-Checker: software for identifying and correcting genotyping errors in microsatellite data. Mol Ecol Notes 4:535-538

Villalejo-Fuerte M, Muñetón-Gómez MS (2002) Tópicos sobre la biología de la almeja burra Spondylus calcifer (Carpenter, 1857). Hidrobiol 12:79-81

Villalejo-Fuerte M, Arellano-Martínez M, Ceballos-Vázquez BP, García-Domínguez F (2002) Reproductive cycle of Spondylus calcifer Carpenter, 1857 (Bivalvia : Spondylidae) in the "Bahía de Loreto" National Park, Gulf of California, Mexico. J Shellfish Res 21:103-108 